\title{
The Innovation Performance of State-owned Enterprises in Indonesia
}

\author{
Andreas Pardyanto ${ }^{1}$ and Avanti Fontana ${ }^{1 *}$ \\ ${ }^{1}$ Faculty of Economics and Business, Universitas Indonesia \\ Email: avanti.fontana@ui.ac.id
}

\begin{abstract}
State-Owned Enterprises (SOEs) play crucial roles in the economy, including in the most advanced ones. SOEs, especially in Indonesia, are facing dynamic changes and need to adapt to rapid environmental changes and high complexities. Internally, they are required to ensure that wealth is created and distributed throughout the nation as mandated by the law to meet the demand of public services and to protect domestic concerns. On the other side, they must improve their competitiveness to deal with global open market competition in both technological and demand changes. SOEs' transformation has been the goal of Indonesia's economic renewal. This paper aimed to understand the SOEs' strategic entrepreneurship processes in developing their capabilities to create systematic innovation performance. Dynamic capability framework is used to explain entrepreneurship and strategic actions through the variables of firm absorptive capacity in the changing environment and the relationship on dynamic innovation capability.
\end{abstract}

Type of Paper: Review

Keywords: dynamic innovation capability; environment; innovation performance; organization factors; organizational learning; state-owned enterprises; strategic entrepreneurship process.

\section{Introduction}

Entrepreneurship in the country level is usually associated with competitiveness and economic growth (Kelley, Singer \& Herrington, 2016). Economic growth is the dependent variable as the result of national entrepreneurial activities, in which SOEs plays as a crucial element of national economic growth (OECD, 2005). In emerging economies, firms often do not seize sufficient advanced resources (such as knowledge) to learn and to develop capabilities (such as technological capabilities) to advance and perform innovation at the equal level as the firms in developed market economies.

Public sector research on entrepreneurship mostly focuses on government organizations at local or regional level (Teske \& Scheider, 1994), or academic institutions (Verreynne \& Luke, 2006). The study of SOEs from strategic entrepreneurship perspectives is tremendously limited, which is surprising given that SOEs face the similar challenges in common with other type of enterprises, private, small and medium, family and multi-national enterprises, competing in an open and free market (Verreynne \& Luke, 2006). Most strategic management 
and entrepreneurship theories also based on the archetypical firm of private-owned and smallmedium enterprises (Peng et al., 2016). How these theories applied to SOEs have not much been studied, specifically the SOEs in emerging economies such as Indonesia.

Strategic entrepreneurship model can explain the importance of innovation process in SOEs, as they are considered traditionally as risk-averse public organizations and need a structured approach to measure the process. The objective of this paper is to understand strategic entrepreneurship processes within SOE's in developing their capabilities to create systematic innovation performance.

\section{Literature Review}

\subsection{Strategic Entrepreneurship}

Pioneered by Ireland et al. (2001); Hitt et al. (2001); and Ireland, Hitt and Sirmon (2003), strategic entrepreneurship has become an interesting topic since the beginning of twenty-first century. Ireland et al. (2001) state that strategic management and entrepreneurship concern with the development of firm wealth creation through the synergy of strategic and entrepreneurial actions domains. Both domains overlap in some general commonalities as depicted on Figure 1.

On the other hand, Ghemawat (2002) mentioned that strategy is related to the firm's longterm survival, which involves the element of how firms acquire and manage resources, and how firms decide to make the utilization of sources toward competitive advantage. On the other hand, Ireland et al. (2003) mentioned that entrepreneurship's main concern is how the firm's take actions to create newness. Miller and Ireland (2005) suggested that strategy and entrepreneurship are the combination of ordered series of decisions made about various issues and phenomena that integrate into strategic entrepreneurship.

Figure 2. describes the combinations strategic management through exploitation-oriented attributes or strategic actions with entrepreneurship through exploration-oriented attributes or entrepreneurship actions to create strategic entrepreneurship that balance exploration and exploitation-oriented attributes to create value through continuous stream of innovation in order the firm to sustain the competitive advantage. Strategic entrepreneurship practices are needed by the firm to adapt to the changes because firms are required to make ordered series of decision to create newness of innovation (Ireland \& Webb, 2007).

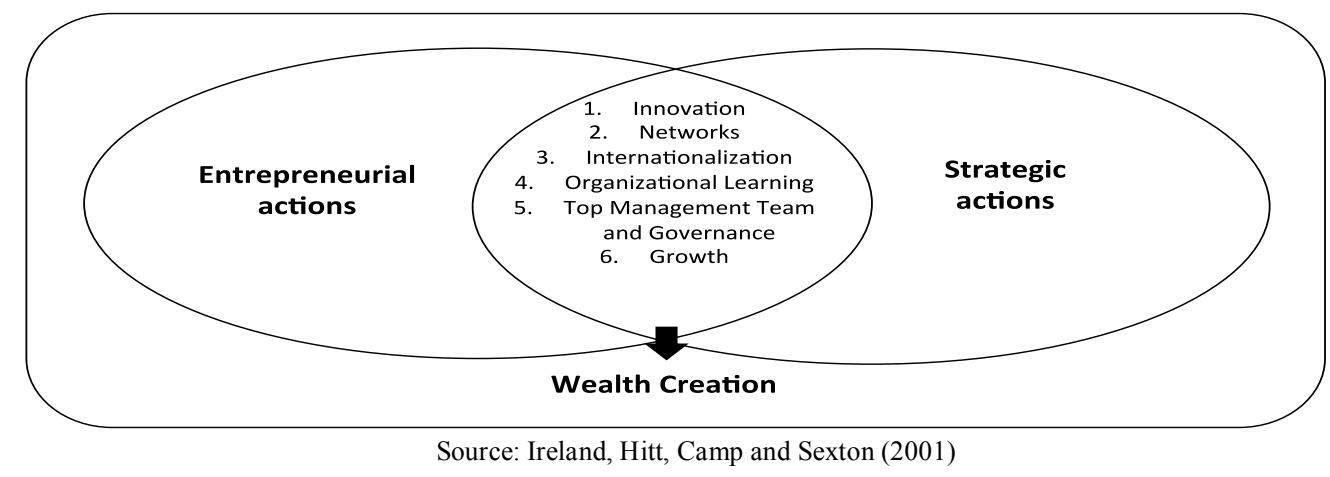

Figure 1. Creating Wealth through Entrepreneurial and Strategic Actions 


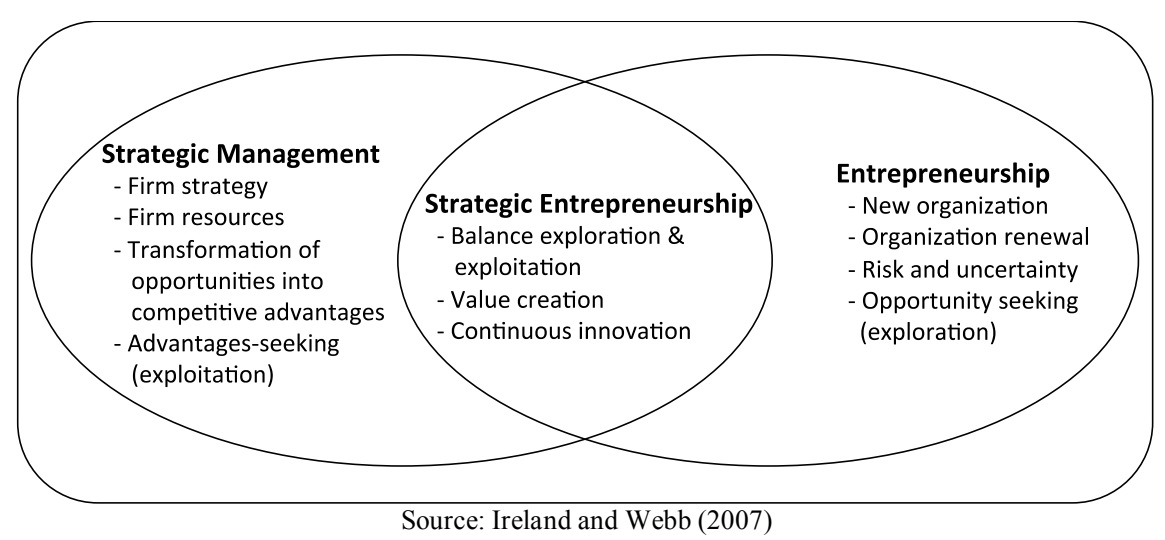

Figure 2. Strategic Entrepreneurship as the Intersection between Entrepreneurship and Strategic Management

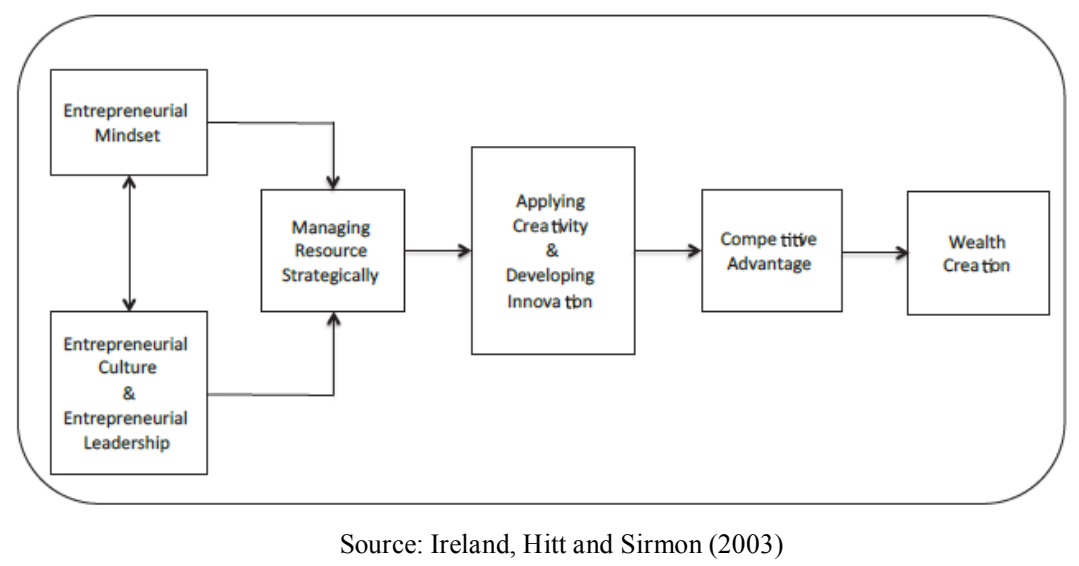

Figure 3. A Model of Strategic Entrepreneurship

\subsection{Strategic Entrepreneurship Model}

Ireland et al. (2003) are among the scholars who first propose strategic entrepreneurship model (Figure 3). Entrepreneurial mindset, culture and leadership are needed by the firm to manage resources through strategic actions and entrepreneurial actions to effectively apply creativity and develop innovation. Firms, regardless of the size, new and established, must engage in both strategic actions and entrepreneurial actions.

The enhanced model of strategic entrepreneurship presented in Figure 4 integrates the environmental influences in the process of strategic entrepreneurship to explain how resources are managed to compete ahead of the competitors (Hitt et al., 2011). This integration describes several distinctive outcomes by offering a more complete view of strategic entrepreneurship model.

The first dimension determines the resources or factors that serve as the input on strategic entrepreneurship. This input includes individual resources, organizational resources and environmental factors. The second dimension is the process. Research indicates that controlling valuable and rare resources will lead to competitive advantage. The managers 


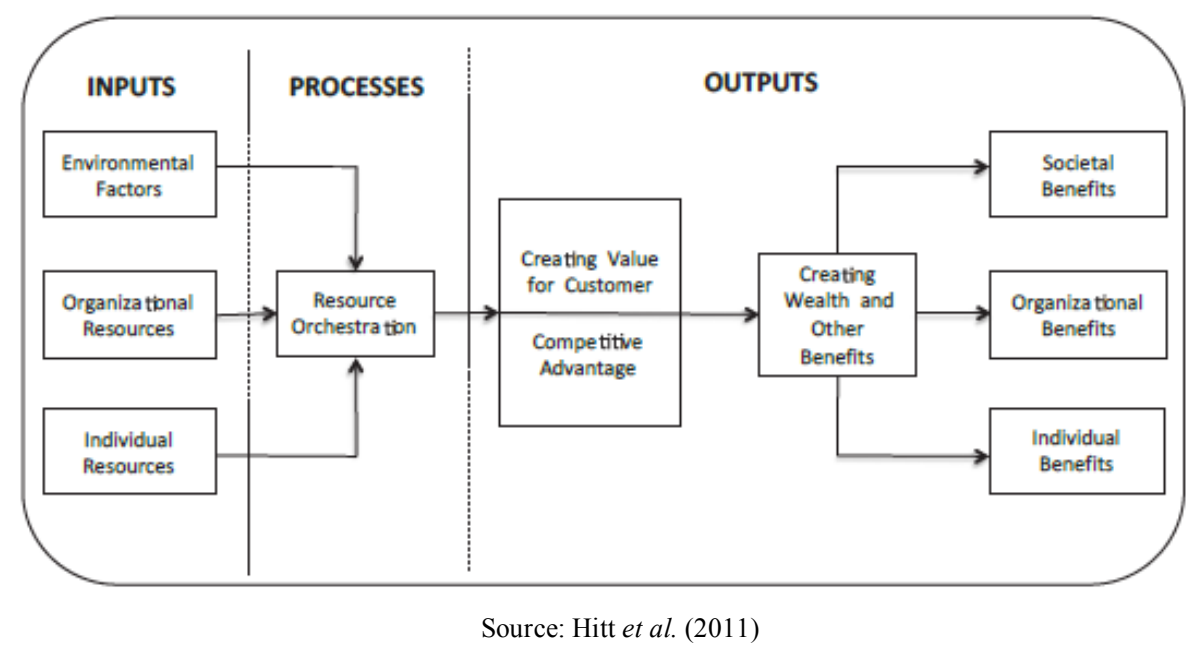

Figure 4. Input-Process-Output Model of Strategic Entrepreneurship

must take further actions to develop and exploit the firm resource advantages and hopefully sustain over the time (Crook et al., 2008). The third dimension of the model is the output and outcome. The processes and actions that involve in strategic entrepreneurship process generate several potential outcomes: social, organizational, and individual benefits.

\subsection{Environmental Factors}

Dess and Beard (1984) proposed three environmental factors as the main characteristics of environmental uncertainty, which are environmental dynamism, complexity and munificence. Environmental dynamism is the frequency of change and unpredictability of environmental factors. Research from Wang \& Li (2008) shows that environmental dynamism has a positive association with innovation through the incentive of exploration. Complex environments will show more organizational uncertainty that requires more information to process to make decision (Duncan, 1972). Castrogiovanni (1991) defines the environmental munificence as the level of resource abundance and a collection of available resources.

Environmental munificence facilitates opportunity identification, resource acquisition and provides the ability to exploit those opportunity and resources to create competitive advantage (Hitt et al., 2011).

\subsection{Organizational Factors}

Researchers have sought to identify organizational factors that can affect the employee to act entrepreneurially, which are organizational culture (Hisrich \& Peters, 1986), organizational structure (Covin \& Slevin, 1991), and managerial support (Kuratko et al., 1993). Independently and in combination, these factors influence the internal environment to create and support entrepreneurial initiatives within the organization.

Jones (2013) comments that organizational structure focuses on standardization, formalization and centralization. Cameron and Quinn (1999) mentions that organizational culture represents the organizational values, assumptions, expectations, collective memories, and definitions in an organization. Ireland et al. (2003) mention that entrepreneurial culture as 


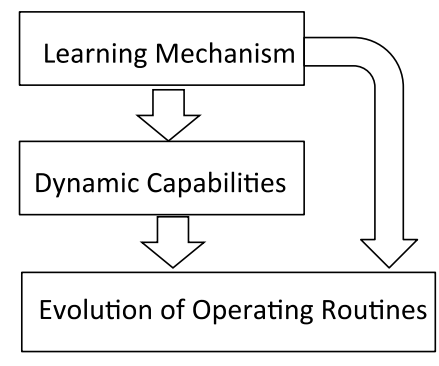

Source: Zollo and Winter (2002)

Figure 5. Learning, Dynamic Capabilities and Operating Routines

resource for organization to encourage entrepreneurship. Organizational leadership is required to develop and grow entrepreneurship in organization (Covin \& Slevin, 1991).

\subsection{Organizational Learning and Dynamic Capability}

Zollo and Winter (2002) proposed deliberate learning as a concept of dynamic capabilities. The organizational learning mechanism occurs from the experience accumulation, knowledge articulation and knowledge codification, that responsible for the development of two set organizational activities.

The first is operating routines that used towards the operational function of the firm and the other as the modification of operating routines that identified as dynamic capabilities (figure 5 ). The operating routines involve the execution of common procedures in daily organization operations and the second type of routines seeks for the changes to current operating routines to do the adaptation.

Dynamic capabilities and learning process evolve in a knowledge evolution cycle. It starts from the external stimuli combine with internal information that will generate variation from the activities of scanning and recombination such information's to generate the ideas. These sets of idea are subject to internal selection of evaluation and legitimation before it diffuse through the replication process before it retain, enactment into new initiatives to create new routines or modify existing ones (figure 6).

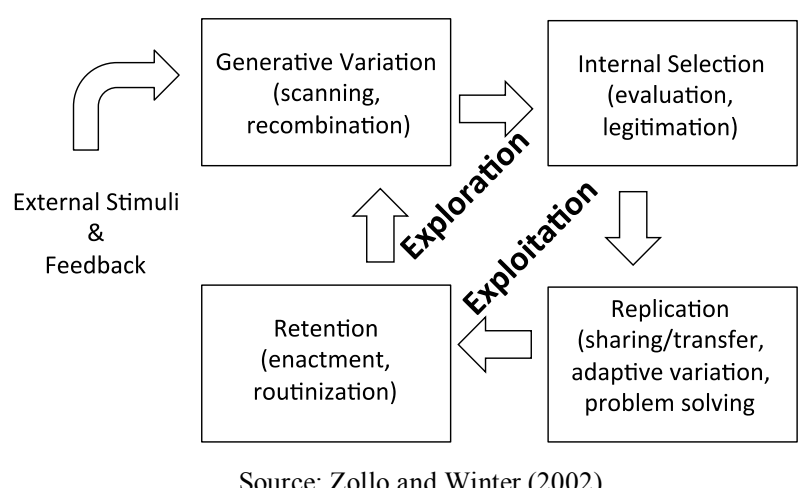

Figure 6. Knowledge Evolution Cycle 
This knowledge evolution cycle involves exploration and exploitation phase. Exploration activities generate the necessary range of new intuition and ideas variation and exploitation activities use the replication of the new ideas and the absorption into existing sets of routines.

Organizational learning in the perspective of strategic entrepreneurship and deliberate learning is a means to renew and modify the knowledge that valuable and difficult to imitate to generate unique organizational capabilities (Hitt, Ireland \& Lee, 2000). Strategic entrepreneurship finds out that organizational learning affects the organizational ability to do continuous innovation and reduce the likelihood that organizational capabilities become outdated (Ireland et al., 2001), therefore help organization to adapt to the environment.

\subsection{Dynamic Innovation Capability}

Innovation capability is strategic for organizations for the reconceptualization of the current business model and modifying existing markets by reconsidering the previous rules to improve value creation and organizational growth (Schlegelmilch, Diamantopoulos \& Kreuz, 2003).

According to Oslo Manual (OECD, 2005), innovation may occur in different format including product, process, organizational and marketing. Product innovation is innovation in terms of goods or services that are new or significantly improved from existing ones, including improvements to technical specifications, components and materials, user friendliness or other functional characteristics. Process innovation is the application of new or improved methods of production. This includes significant changes to the techniques, equipment and / or software used. Organizational innovation is the adoption of new methods in the company's business practices, workplace or external relationships with other institutions. Marketing innovation is the implementation of new marketing methods that involve significant changes in product or packaging design, product placement, promotion or pricing.

\subsection{Innovation Performance}

This research adopts the concept of innovation performance and its measures as a proxy to organizational performance in a specific term as innovation is the instrument to strategic entrepreneurship. Innovation performance is viewed as a mechanism to measure the performance of the strategic entrepreneurship in a systematic way that represents the input, process, and output performance of innovation (Fontana \& Musa 2016; Ariyanto, Fontana \& Affif, 2015).

Internal aspect of innovation performance (input performance) measures the perceptual organizational innovativeness, climate and culture before, during and after an innovation process. This dimension measures the effectiveness of internal tangible and intangible resources (such as climate, culture, and resources) to innovation. Technical performance point to the organization's ability to realize creative and innovative ideas into real products (goods and/or services), and other form of innovation outputs resulted from product, process, organization and marketing innovation (OECD, 2005). 


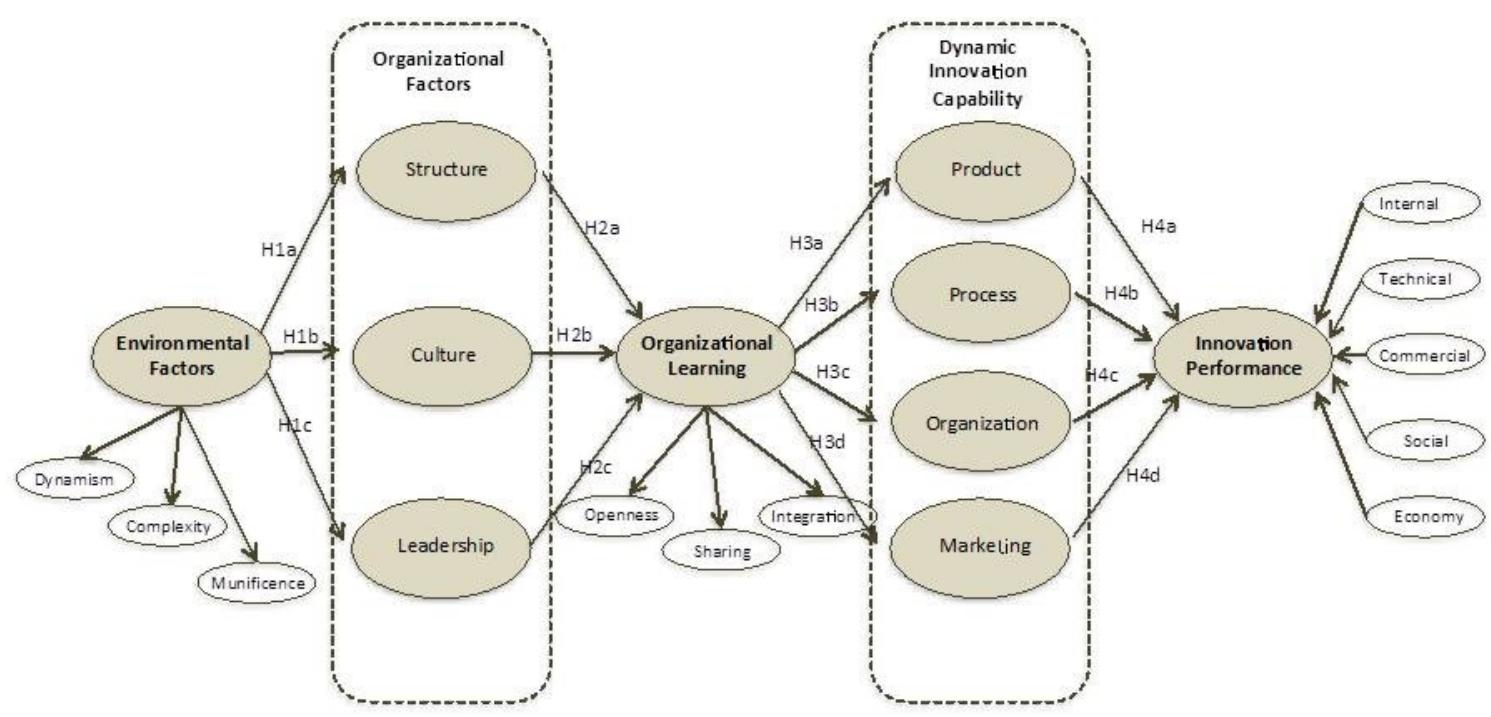

Figure 7. Proposed Research Model

Commercial performance refers to the organization ability in diffusing or distributing the innovative products in the market. It basically indicates that the innovation process has produced goods and/or services that can be sold to the market. Social performance points to the positive impact creates by the organization through their innovation input, process, and output, not only to the pertinent stakeholders but also to the general community and society as part of their corporate social responsibility and their corporate-shared-values actions. Economic performance deals with the financial performance of an innovative output that has passed the commercialization phase or the diffusion phase in general.

\section{Proposed Research Model}

The following proposed research model is developed from the three dimensions inputprocess-output model (Hitt et al., 2011), in integration with the theory compiled from the literature review.

\section{Hypothesis development}

Environmental factors facilitate firms in acquiring resources and identifying opportunities as well as the ability to exploit the resources and opportunities to create competitive advantage (Dess \& Beard, 1984). Hence, the following hypotheses was developed.

H1a: The higher the enacted environmental factors, the more entrepreneurial the SOE's organizational structure.

H1b: The higher the enacted environmental factors, the more entrepreneurial the SOE's organizational culture.

H1c: The higher the enacted environmental factors, the more entrepreneurial the SOE's organizational leadership. 
Organizational factors influence the employee to act entrepreneurial through the organizational culture (Hisrich \& Peters, 1986), organizational structure (Covin \& Slevin, 1991), and managerial support (Kuratko et al., 1993).

H2a: The more entrepreneurial the SOE's organizational structure, the higher the SOE's organizational learning capability.

H2b: The more entrepreneurial the SOE's organizational culture, the higher the SOE's organizational learning capability.

H2c: The more entrepreneurial the SOE's organizational leadership, the higher the SOE's organizational learning capability.

Organizational learning affects the organizational ability to do continuous innovation and reduce the likelihood that organizational capabilities become outdated (Ireland et al., 2001). Innovation capability categories follow Oslo Manual (OECD, 2005), which are product, process, organization and marketing innovations.

H3a: The higher the SOE's organizational learning capability, the higher the SOE's product innovation capability.

H3b: The higher the SOE's organizational learning capability, the higher the SOE's process innovation capability.

H3c: The higher the SOE's organizational learning capability, the higher the SOE's organizational innovation capability.

H3d: The higher the SOE's organizational learning capability, the higher the SOE's marketing innovation capability.

Continuous innovation capability is needed by the organizations to improve value creation and organizational growth (Schlegelmilch, Diamantopoulos \& Kreuz, 2003).

H4a: The higher the SOE's product innovation capability, the higher the SOE's innovation performance.

H4b: The higher the SOE's process innovation capability, the higher the SOE's innovation performance.

H4c: The higher the SOE's organizational innovation capability, the higher the SOE's innovation performance.

H4d: The higher the SOE's marketing innovation capability, the higher the SOE's innovation performance.

While the innovation performance dimensions use a comprehensive approach from Fontana and Musa (2016), who suggested five dimensions of innovation performance: internal, technical, commercial, economic and social performances. 


\section{Research Methodology}

This research aimed to examine the organizational capability within the state-owned companies (SOEs) in Indonesia. Indonesia has 119 SOEs under the coordination of Ministry of State-Owned Enterprises, ranging from transport and banking, to pharmaceuticals with assets of more than $\$ 300$ billion (BUMN, 2016). Yet, the SOEs still feel doubtful to be able to compete in ASEAN market, for instance no Indonesia SOE banks have expanded to another ASEAN countries and thus there is a fear that they will lose the competition when the stronger bank from Singapore or Malaysia start arriving.

This research use mixed qualitative and quantitative methodology. In-depth interview and focus group discussion has been done with 12 SOE officers from 10 SOEs to discuss the model and measurement variables. Questionnaire has been developed and will be distributed to the respondents in 158 SOEs and its subsidiaries (purposive sampling) who responsible for the firms' strategic entrepreneurship process and the growth of the firms. Practically all the information needed that not limited to the board of directors, therefore the information that will be obtained will describe the organization.

There will be with two types of data collected from questionnaires, descriptive and inferential statistics using six Likert scale. This inferential statistics data will be tested and analyzed using Structural Equation Modeling, Partial Least Squares (SEM-PLS). SEM-PLS will be used to test the relationships among the indicators or observed variables, to provide a quantitative test of a hypothesized theoretical model (Schumacker \& Lomax, 2012). SEMPLS is flexible to use and its statistical power is relatively high.

The goal of SEM analysis is to determine how theoretical model supported by sample data using statistics and hypothesis testing. SEM analysis is inferential statistics, to draw conclusions and make decisions based on the analysis. This analysis usually taken from particular sample of a population and the results of the analysis were generalized in some context to the population.

\section{Research Contribution}

The objective of this paper is to identify SOEs strategic entrepreneurship process in managing innovation through the measurement of innovation performance. Five important construct has been developed as the model to be measured and tested.

From the empirical results, this research is expected to achieve two main contributions: to provide empirical evidence on what are the factors that drive the strategic entrepreneurship process through the development of knowledge as resources that needed by entrepreneurial and strategic actions for operational agility to adapt for the changing environment. Another main contribution is the examination on the role of dynamic innovation capability in driving strategic entrepreneurship process to foster SOEs innovation.

The result analysis also expected to contribute on managerial practices, concentrating on the development and integration of organizational factors to enhance innovation capability and innovation performance. This process can stimulate on how dynamic innovation capability will contribute to the success and sustainability of innovation performance in SOEs. 
The state sector has always been an important element of many economies. SOEs that traditionally been oriented towards domestic markets, with a growing integration through trade and investment, are increasingly compete with private and multinational firms in the global markets. Research that focus on SOEs' innovation and organizational learning has been disregarded. As many other organizations nowadays, SOEs also need to compete, growth and adapt.

\section{References}

\section{Journal articles}

Aryanto, R., Fontana, A., and Afiff, A.Z. (2015). Strategic Human Resource Management, Innovation Capability and Performance: An Empirical Study in Indonesia Software Industry. Procedia - Social and Behavioral Sciences, 211, 874 879.

BUMN. 2016. "Statistik jumlah BUMN. Perkembangan jumlah BUMN." Accessible online: http://bumn.go.id/halaman/238/Statistik.Jumlah.BUMN

Castrogiovanni, G.J. (1991). Environmental munificence: A theoretical assessment. Academy of Management Review, 16(3), 542-565.

Covin, J.G., and Slevin, D.P. (1991). A conceptual model of entrepreneurship as firmbehavior. Entrepreneurship: Theory and Practice, 16, 7-25.

Crook, T.R., Ketchen, D.J., Combs, J.G., and Todd, S.Y. (2008). Strategic resources and performance: A meta-analysis. Strategic Management Journal, 29(11), 1141- 1154.

Dess, G.G., and Beard, D. (1984). Dimensions of organizational task environments. Administrative Science Quarterly, 29(1), 52-73.

Duncan, R.B. (1972). Characteristics of organizational environment and perceived environmental uncertainty. Administrative Science Quarterly 17(2), 313-327.

Fontana, A., and Musa, S. (2016). Entrepreneurial Leadership Measurement Validation in Innovation Management. Forthcoming in The International Journal of Innovation Science.

Ghemawat, P. (2002). Competition and business strategy in historical perspective. Business History Review, 76(1), 37-74.

Hisrich, R.D., and Peters, M.P. (1986). Establishing a new business venture within a firm. Journal of Business Venturing, 1, 30-332.

Hitt M.A., Ireland R.D., and Lee, H. (2000). Technological learning, knowledge management, firm growth and performance. Journal of Engineering and Technology Management, 17, 231-246. 
Hitt, M.A., Ireland, R.D., Camp, S.M., and Sexton, D.L. (2001). Strategic entrepreneurship: Strategies for wealth creation. Strategic Management Journal, 22(3-4), 479-491.

Hitt, M.A., Ireland, R.D., Sirmon, D.G., and Trahms, C.A. (2011). Strategic entrepreneurship: creating value for individuals, organizations, and society, Academy of Management Perspectives 25, 57-75.

Ireland, R.D., Hitt, M.A., Camp, S.M., and Sexton, D.L. (2001). Integrating entrepreneurship and strategic management actions to create wealth. Academy of Management Executive, 15(1), 49-63.

Ireland, R. D., Hitt, M. A., and Sirmon, D. G. (2003). Strategic entrepreneurship: The construct and its dimensions. Journal of Management, 29(6), 963-989.

Ireland, R.D., and Webb, J.W. (2007). A cross disciplinary exploration of entrepreneurship research. Journal of Management, 33(6), 891-927.

Kuratko, D.F., Hornsby, J.S., Naffziger, D.W., and Montagno, R.V. (1993). Implementing entrepreneurial thinking in established organizations. SAM Advanced Management Journal, 58(1), 28-33.

Miller, C.C., and Ireland, R.D. (2005). Intuition in strategic decision-making: Friend of foe in the fast-paced 21st century? Academy of Management Executive, 19 (1), 19-30.

Peng, M.P., Bruton, G.D., Stan, C.V., and Huang, Y. (2016). Theories of the (state-owned) firm. Asia Pacific Journal of Management, Published online, 03 May 2016.

Schlegelmilch, B.B., Diamantopoulos, A. and Kreuz, P. (2003). Strategic innovation: the construct, its drivers and its strategic outcomes. Journal of Strategic Marketing, vol. $11,117-132$.

Teske, P., and Scheider, M. (1994). The bureaucratic entrepreneur: the case of city manager. Public Administration Review, 54 (4), 331-341.

Verreynne, M.L., and Luke, B. (2006). Exploring Strategic Entrepreneurship in the public sector. Qualitative Research in Accounting \& Management, III (1), 4-26.

Wang, H., \& Li, J. (2008). Untangling the effects of over-exploration and over-exploitation on organizational performance: The moderating role of environmental dynamism. Journal of Management, 34(5), 925-951.

Zollo, M., and Winter, S.G. (2002). Deliberate learning and the evolution of dynamic capabilities. Organization Science, 13, 339-351.

\section{Books}

Argyris, C. and Schon, D.A. (1996). Organizational learning II: Theory, method and practice. Reading, MA: Addison-Wesley Publishing. 
Cameron, K.S., and Quinn, R.E. (1999). Diagnosing and changing organizational culture: Based on the competing values framework. Reading, MA: Addison-Wesley.

Jones, G. (2013). Organizational Theory, Design, and Change, (7th ed.), Pearson, Harlow, England.

Kelley, D., Singer, S, \& Herrington, M. (2016). Global Entrepreneurship Monitor. 2015/2016 Global Report. Global Entrepreneurship Research Association

Organization for Economic Co-operation and Development (OECD, 2005). Guidelines on Corporate Governance of State Owned Enterprises: a Survey of OECD Countries. OECD Publishing, Paris.

Schumacker, R. E., and Lomax, R. G. (2012). A Beginner's Guide to Structural Equation Modeling, $3^{\text {rd }}$ edition. Lawrence Erlbaum Associates, Inc., Mahwah, NJ 